Journal of Economics and Behavioral Studies

Vol. 4, No. 4, pp. 190-193, Apr 2012 (ISSN: 2220-6140)

\title{
Phillips Curve or Locus Critique: Time Series Evidence from Pakistan
}

\author{
${ }^{*}$ Ihtisham Ul Haq, Shaista Khan, Alam Khan, Ejaz Ahmed \\ Kohat University of Science and Technology (KUST), Pakistan \\ *ihtishamamin_99@yahoo.com
}

\begin{abstract}
Some economic problems facing by any economy are addressed such that minimum levels of these are acceptable. Inflation and unemployment are among such macroeconomic issues of which certain minimum level of both are accepted by economists. Nature of relationship between unemployment and inflation is important in economic literature. This study was performed to find this nature for a developing country. Time series data on both variables was analyzed for Pakistan from 1974 to 2010. ADF test was applied for detection of non-stationary. Problem of non-stationary was detected when variables were at level, which was eliminated by taking variables at first difference. Johansen co-integration confirmed one cointegration vector, which suggested the presence of long run relation between variables. VECM was used to find short and long run estimates. A short run relation was witnessed when unemployment worked as dependent variable and inflation as explanatory variable. This model was in equilibrium and thirty five percent disequilibria were adjusted annually as ECT value suggested. Inflation had a significant positive association with unemployment in study period. This study supported the Locus critique as opposed to Phillips curve hypothesis. Policy makers should pay special attention to this relationship between inflation and unemployment when they are going to design macroeconomic policies for Pakistan's economy.
\end{abstract}

Key words: Unemployment, Inflation, Co-integration, VECM, Locus Critique

\section{Introduction}

Certain minimum level of inflation is referred to price stability and is considered good for economic growth. When it is beyond this acceptable level and out of control, then it needs special attention from policy makers. Similarly, certain minimum level of unemployment, known as full employment, is acceptable to economists. Thus, fluctuations in both these variables are very important to economists. Unemployment rate and inflation association with each other is very important in macroeconomic literature. This correlation provides foundation for decision making at macroeconomic level. Phillips (1958) was among the earlier economists who found a negative association between unemployment and Inflation for UK economy. This negative association since then is known as Phillips curve. Low inflation is accompanied by high unemployment and vice versa as proposed by this curve. Inflation and unemployment are two major problems of any economy. Both these problems need special attention. Macroeconomic policies of Pakistan are centered to achieve price stability and high employment. Global and domestic recession is a big hurdle in these objectives. Government is taking steps to stimulate domestic investment, which may be beneficial in alleviation of unemployment. Social and political stability plays an important role in economic growth, but our economy is lacking both of these (GoP, 2011). Mainly, the aim of monetary policy is to have price stability. When inflation is undesirable then restrictive monetary policy is being adopted. Private investment discourages at high rate of interest, which compel economy to bear high unemployment. All this is based on hypothesis of Phillips curve. Empirical studies have been carried out to accept or reject this hypothesis but mostly these studies were done in developed countries. This current study is based on this hypothesis for a developing country. It is obvious to know the role of relationship between inflation and unemployment in designing macroeconomic policies for an economy. Findings of this study will help policy makers to achieve contrasting objectives of price stability and full employment in Pakistan. Furthermore, this study is going to explain theoretical association of inflation and unemployment empirically. 


\section{Literature Review}

Phillips (1958) has carried out his research to find a correlation between inflation and unemployment rate for period 1861-1957 in United Kingdom (UK). This study found a negative relation between these variables for UK in the period under consideration. Since then this negative association between inflation and unemployment is known as Phillips curve. Samuelson and Solow (1960) conducted study on relationship between inflation and unemployment rates. This study was done for United States of America. This study discovered an inverse relation between unemployment and inflation rates. This result supported the existence of Phillips curve. Some empirical studies opposed this inverse relationship between inflation and unemployment rates. Friedman (1968) and Phelps (1967) had criticized the idea of existence of a trade-off between inflation and unemployment rate. Similarly, Lucas (1976) opposed strongly the existence of trade-off between these economic variables. He argued that a positive correlation is present between these variables. This is known as "Locus Critique". He argued that if workers anticipate expected inflation then they would ask for high wages, so high inflation may be accompanied by high unemployment. Same positive association between these variables under consideration was confirmed in different studies carried out (Bayer and Farmer, 2007: Berentsen, Menzio and Wright 2008). On other hand, we have studies, which were carried out to examine association between inflation and unemployment rate and found negative correlation for these variables. Karanassou, Sala and Snower (2003) conducted their study using panel data for twenty-two European countries. Result of their study confirmed a long run trade off between inflation and unemployment rate. Similarly, same result of negative association for these variables was found for Germany by Franz (2005), Schreiber, and Wolters (2007). It can be concluded from above discussion that correlation between inflation and unemployment is uncertain. This relation may be positive or negative depending on how different economies behave in certain period.

\section{Methodology}

The Data and Variables: Time series data for period 1974-2010 for Pakistan's economy was utilized in this study. Unemployment and inflation are variables of this study. Data on both variables were taken from World Development Indicators (WDI) and Economic Survey of Pakistan (various issues). These sources were chosen because of reliability and most researchers used it consistently. Variables of study are discussed below:

Unemployment (Un): Any person at age of ten or above will be considered unemployed who is workless but has willing to do work (GoP, 2011). Unemployment is being measured in total numbers of persons unemployed during specific year. Its frequency is annual from 1974 to 2010. Economy bears cost in form of unutilized resources when there is high unemployment. It shrinks capacity of the economy.

Inflation (In): A constant rise in general price level over a period is called inflation. Consumer price index (CPI) is one of the ways to measure inflation. Base year for CPI is 2000. Annual data is been taken on CPI from 1974 to 2010. Inflation enhances cost of living. It is of great concern for fix income earners. This study is interested to find long run relation of inflation with unemployment in Pakistan. The following model based on simple regression will be estimated for this purpose.

$$
l U n_{t}=\phi_{0}+\phi_{1} l I n_{t}+e_{t}
$$

Where $I U n_{t}$ and $l I n_{t}$ are natural log of unemployment and inflation respectively. Residual term is denoted by $e_{t}$.

Econometric Techniques: Following are the techniques adopted in this study.

Augmented Dickey-Fuller test (ADF) for unit root analysis: Usually time series data suffers from problem of non-stationary. Spurious regression may arise to this problem. Data should be check for unit root before analysis. Augmented Dickey-Fuller test will be used for this purpose (Dickey and Fuller, 1979, 1981).

Johansen Co-integration Test for Long Run Relationship: When variables are integrated of the same order Johansen co-integration test can be applied to find long run relation among variables (Johansen, 1988: 
Johansen and Julius, 1990). This test not only finds the long run relationship between variables but also finds long run coefficients of variables. This can be done by applying causality based on Vector Error Correction Model (VECM). All variables in difference form are taken endogenous in VECM. Numbers of equations depends on numbers of variables. Dependent variable in each equation depends on its own lag, explanatory variables in lags, error correction term and on residual. Error correction term shows adjustment in previous period towards equilibrium. VECM with two variables are written as follows:

$$
\begin{aligned}
& \Delta U n_{t}=\delta_{1}+\sum_{i=1}^{j} a_{1 i} \Delta U n_{t-1}+\sum_{i=1}^{j} \beta_{1 i} \Delta I n_{t-1}+\alpha_{1} \zeta_{t-1}+\mathcal{E}_{1 t} \\
& \Delta I n_{t}=\delta_{2}+\sum_{i=1}^{j} a_{2 i} \Delta U n_{t-1}+\sum_{i=1}^{j} \beta_{2 i} \Delta I n_{t-1}+\alpha_{2} \zeta_{t-1}+\varepsilon_{2 t}
\end{aligned}
$$

\section{Results and Discussion}

Result of Unit Root Test: ADF test showed that data of both variables were non-stationary at level and became stationary by taking their first difference. This result is shown in table 1 below. IUn and IIn is $\log$ of unemployment and inflation respectively.

Table 1: Unit root test

\begin{tabular}{llll}
\hline Variables & ADF Level & First difference & Order of Integration \\
\hline IUn & -1.462826 & $-9.519673^{*}$ & $(1)$ \\
IIn & -2.046698 & $-2.896631^{*}$ & $(1)$ \\
\hline
\end{tabular}

Note: * indicates rejection of null hypothesis of non-stationary.

Long run relationship: Johansen co-integration test: A long run relation was confirmed by this test between variables. Its result is provided in table 2 . Single co-integration vector was found between variables, which were confirmed by Trace, and maximum Eigen statistics. Values of trace statistics and maximum Eigen statistics were greater than their critical values at five percent.

Table 2: Co-integration test

\begin{tabular}{lllll}
\hline No of CE(s) & Trace Statistics & $\mathbf{5 \%}$ CV & Max. Eigen statistics & 5\% CV \\
\hline None* & 39.05031 & 29.79707 & 25.11835 & 21.13162 \\
At most 1 & 13.93196 & 15.49471 & 11.74509 & 14.26460 \\
\hline
\end{tabular}

VECM for Causality Analysis: VECM was performed to capture causality between variables. Its result is provided in table 3. Inflation had a short run relation with unemployment and model was in equilibrium when unemployment was taken as dependent variable. Thirty-five percent disequilibria were adjusted every year, which was suggested by Error correction term (ECT). Model neither was in equilibrium nor was short run relationship found between unemployment and inflation when inflation was taken as dependent variable.

Table 3: Short run estimates of VECM

\begin{tabular}{lcll}
\hline Dependent Variable & D IUn & D IIn & Lagged ECT \\
\hline$D$ IUn(-1) & - & -0.031394 & -0.355767 \\
& & $(-1.89884)$ & $(-1.97421)$ \\
$D \operatorname{In}(-1)$ & 0.287443 & - & 0.078047 \\
& $(0.25616)$ & & $(4.33589)$ \\
\hline
\end{tabular}

Long Run association of Inflation with Unemployment: Result of long run relation based on VECM is given in table 5. It was evident that there was a significant positive relation between unemployment and inflation in the study period. One percent increase in inflation will bring 3.22 percent increase in unemployment. This result opposed the hypothesis put forward by Phillips (Phillips, 1958) that a trade off is existed between these two economic variables. It resembling to the findings of Phelps (1967), Friedman (1968) and Lucas (1976). This empirical evidence from Pakistan supported Locus critique that positive relation is there between unemployment and inflation. Bayer and Farmer, (2007) and Berentsen, Menzio and Wright (2008) confirmed positive correlation between these variables. This study navigated research studies of Franz (2005), Schreiber, and Wolters (2007) who conducted their studies for Germany. 
Table 4 Long run estimation of VECM

\begin{tabular}{lll}
\hline Dependant variable: $\boldsymbol{I U n}(-\mathbf{1})$ & \\
\hline Regressor & Coefficient & $\boldsymbol{t}$-Values \\
\hline $\operatorname{In}(-1)$ & 3.22146 & -6.03255 \\
\hline
\end{tabular}

\section{Conclusion}

Correlation between inflation and unemployment has special attention from economists. This relation may be positive or negative between these variables. Sole objective of this study was to determine the long run association between unemployment and inflation in a developing country. Annual time series data for Pakistan was analyzed from 1974 to 2010. Data of both series were found non-stationary at level by applying ADF unit root test. Both series were made free of this problem by taking variables at first difference. To find long run relationship, co-integration test proposed by Johansen was applied. This test affirmed single cointegration vector, which stated that there is a long run relationship between variables. Causality was tested through VECM. This model enables to estimate long run coefficient and short run dynamics. Its result concluded a positive long run correlation of inflation with unemployment. Further VECM result showed a short run association of inflation with unemployment. Model was in equilibrium and disequilibria due to external factors was adjusted about thirty-five percent every year. This was suggested by value of ECT. It can be concluded that this study supported Locus critique as compared to findings of Phillips. This study affirmed that relation between unemployment and inflation is subject to economy and may be positive or negative depending on economic situation of the country. It is suggested that panel study of developing countries should be carried out to have a clear picture of this relation. It may be suggested on basis of this finding that steps are needed to curtail unemployment with out worrying too much for controlling the inflation.

\section{References}

Berentsen, A., Menzio, G. \& Wright, R. (2008). Inflation and unemployment in the end. Working Paper 13924, National Bureau of Economic Research.

Beyer, A. \& Farmer, R. E. (2007). Natural rate doubts. Journal of Economic Dynamics and Control, 31(3), 797-825.

Dickey, D. \& Fuller, W. (1979). Distribution of the Estimators for Autoregressive Time Series with a Unit Root. Journal of the American Statistical Association, 74(366), 427-431.

Dickey, D. \& Fuller, W. (1981). Likelihood Ratio Tests for Autoregressive Time Series with a Unit Root. Econometrica, 49(4), 1057-1072.

Franz, W. W. (2005). The (german) nairu please stand up. German Economic Review, 6(2), 131-153.

Friedman, M. (1968). The Role of Monetary Policy. American Economic Review, 58, 1-17.

Government of Pakistan. (2011). Pakistan Economic Survey, Ministry of Finance, Islamabad, Pakistan.

Johansen, S. (1988). Statistical Analysis of Co integration Vector. Journal of Economic Dynamics and Control, 12(2/3), 231-254.

Johansen, S. \& Juselius, F. (1990). Maximum likelihood estimation and inference on co integration - with application to the demand for money. Oxford Bulletin of Economics and Statistics, 52, 169-210.

Karanassou, M., Sala, H. \& Snower, D. J. (2003). The European Phillips Curve: Does the nairu exist? IZA Discussion Papers 876, Institute for the Study of Labor (IZA).

Lucas, R. E. (1976). Econometric Policy Evaluation: A Critique. Carnegie-Rochester Conference Series on Public Policy, 1, 19-46.

Phelps, E. (1967). Phillips Curve, Expectation of Inflation, and Optimal Inflation over Time. Economica, 34, 254-281.

Phillips, A.W. (1958). The Relationship between Unemployment and the Rate of Change of Money Wage Rates in the United Kingdom. Economica, 25, 258-299.

Samuelson, P. A. \& Solow, R. M. (1960). Analytical Aspect of Anti-inflation Policy. American Economic Review, 50, 177-194.

Schreiber, S. \& Wolters, J. (2007). The long-run Phillips curve revisited: Is the nairu framework dataconsistent? Journal of Macroeconomics, 29(2), 355-367. 